\title{
KIERUNKI I UWARUNKOWANIA POLITYKI ZAGRANICZNEJ JEMENU W LATACH 1990-2014
}

Słowa kluczowe: Jemen, polityka zagraniczna, Arabska Wiosna, USA, Polska

Keywords: Yemen, foreign policy, Arab Spring, USA, Poland

\section{WSPÓłCZESNY JEMEN - RYS HISTORYCZNY}

konstytuowanie się współczesnego Jemenu jest związane z licznymi konfliktami na Półwyspie Arabskim, zarówno między siłami lokalnymi, jak i wywołanymi wpływami mocarstw. Aby przybliżyć czytelnikowi złożone i skomplikowane dzieje tego państwa, należy zacząć od pojawienia się islamu w Jemenie wraz z podbojami z czasów proroka Muhammada w VII w. Następnie, od IX w. niemal przez 1000 lat imamowie szyiccy (zajdyccy) rządzili południowo-zachodnią częścią Półwyspu Arabskiego. W XVI w. wraz z ekspansją Imperium Osmańskiego rozpoczął się okres tureckiej zależności².

\footnotetext{
${ }^{1}$ Katedra Teorii Stosunków Międzynarodowych, Instytut Prawa Międzynarodowego, Unii Europejskiej i Stosunków Międzynarodowych, Wydział Prawa i Administracji, Uniwersytet Kardynała Stefana Wyszyńskiego w Warszawie.

2 J. Zdanowski, Historia Bliskiego Wschodu w XX wieku, Ossolineum, Wrocław 2010, s. 18 i n.
} 
Historię współczesnego Jemenu rozpoczyna era monarchii, którą inicjuje odzyskanie niepodległości od Turcji przez północną część tego państwa 1 listopada 1918 r. Stało się to możliwe dzięki wysiłkom szyickiej (zajdyckiej) dynastii Al-Mutawakkilów. Jahja Hamid ad-Din (1869-1948) ogłosił się królem w 1926 r., pozostając jednocześnie religijnym przywódcą lokalnych szyitów. Wskutek dążeń do budowy tzw. Wielkiego Jemenu obejmującego, poza dzisiejszym terytorium tego państwa, także ziemie leżące w Arabii Saudyjskiej (Asir, Nadżran i Dżizan) oraz Omanie (Zufar), w 1934 r. doszło do kilkumiesięcznej wojny z Arabią Saudyjską, po zakończeniu której uregulowano granicę między zwaśnionymi państwami na mocy traktatu z miasta Ta'if, odnawianego cyklicznie co 20 lat $^{3}$. Stolicą państwa w tym okresie pozostawała Sana. W 1945 r. Jemen zaistniał szerzej w regionalnych stosunkach międzynarodowych współtworząc Ligę Państw Arabskich.

Po śmierci imama Jahji Hamida ad-Dina podczas zamachu stanu w 1948 r., kraj na kilka miesięcy pogrążył się w chaosie. Po stłumieniu powstania władzę objął syn Jahji, Ahmad bin Jahja. W latach 50. XX w. w polityce zagranicznej Jemenu narosły problemy wynikające z prób powrotu do budowy Wielkiego Jemenu w polityce zagranicznej, co skutkowało konfliktem z Wielką Brytanią, kontrolującą od XIX w. południowo-wschodnią część Jemenu, w szczególności porty nad Zatoką Adeńską (Brytyjski Protektorat Adenu oraz Hadramawt). Dodatkowo zacieśnienie współpracy z naserowskim Egiptem od podpisania sojuszu obronnego między obydwoma państwami w 1956 r. wpisywało się w próby zwiększenia prestiżu międzynarodowego Sany. W duchu panarabizmu w latach 1958-1961 Jemen był członkiem Federacji Związku Państw Arabskich, wchodząc tym samym w sojusz ze Zjednoczoną Republiką Arabską (czyli z Egiptem i Syrią) ${ }^{4}$.

Po śmierci imama Ahmada w 1962 r. i przejęciu władzy przez jego syna Muhammada al-Badra stosunki z Egiptem uległy rozluźnieniu. Nowy imam rządził raptem kilka miesięcy i został pozbawiony władzy na drodze zamachu stanu przez dowódcę gwardii królewskiej, Abd Allaha as-Sallala oraz sprzymierzonych z nim oficerów. Nowy przywódca utworzył w miejsce mo-

${ }^{3}$ Ostatnie przedłużenie ważności tego traktatu na kolejne 20 lat miało miejsce w $1995 \mathrm{r}$.

${ }^{4}$ Sh. Weir, A Tribal Order: Politics and Law in the Mountains of Yemen, University of Texas Press Austin, Austin 2007, s. 256 i n. 
:::: Jan Bury, Kierunki i uwarunkowania polityki zagranicznej Jemenu...

narchii Jemeńską Republikę Arabską (tzw. Jemen Północny), przy wsparciu ze strony Egiptu. W tym samym czasie stronnicy obalonego Muhammada al-Badra podjęli próby odzyskania władzy z pomocą Arabii Saudyjskiej oraz Jordanii, co skutkowało wybuchem wojny domowej. Po wycofaniu sił egipskich z Jemenu, konflikt wygasł wraz z pojednaniem walczących stron. W 1970 r. Arabia Saudyjska uznała granicę z Jemeńską Republiką Arabską ${ }^{5}$.

Dzieje Północnego Jemenu, państwa z aktywnymi elementami demokracji, najpierw monarchii w latach 1918-1962, a następnie republiki do 1990 r. czyli momentu fuzji z Południowym Jemenem - były niemal zawsze burzliwe. Dwóch prezydentów, Ibrahim al-Hamdi i Ahmad al-Haszimi, straciło życie w zamachach. Ostatecznie, w 1978 r. władzę przejął Ali Abd Allah Salih, który sprawował ją nieprzerwanie do zjednoczenia w 1990 r., a następnie aż do 2012 r.

Brytyjska obecność na południu dzisiejszego Jemenu datuje się na $1838 \mathrm{r}$. wraz z przejęciem kontroli nad Adenem. W rok później Brytyjska Kompania Wschodnioindyjska doprowadziła do brytyjskiej okupacji regionu celem powstrzymania piractwa uszczuplającego zyski z dalekomorskiego handlu Londynu z Indiami. Znaczenie Adenu jako portu i stacji nawęglania parowców wzrosło istotnie po otwarciu Kanału Sueskiego w 1869 r. Co istotne, Aden był zaliczany do dalekowschodnich posiadłości Wielkiej Brytanii, czyli Brytyjskich Indii. W 1937 r. został przekształcony w kolonię, a w 1963 r., już w dobie dekolonizacji, wszedł w skład Federacji Arabii Południowej, jednoczącej emiraty nad Zatoką Adeńską. Siły brytyjskie opuściły Aden w 1967 r., co umożliwiło utworzenie 30 listopada tegoż roku Ludowej Republiki Południowego Jemenu (tzw. Jemenu Południowego). W związku z przejęciem władzy w Adenie przez marksistowski Narodowy Front Wyzwolenia, 1 grudnia 1970 r. państwo zostało przekształcone w Ludowo-Demokratyczną Republikę Jemenu (LDRJ), co skutkowało natychmiastowym zwrotem ku blokowi wschodniemu. Najistotniejsze w tym kontekście wydaje się zyskanie baz morskich w Jemenie przez marynarkę wojenną Związku Radzieckiego, co wpisywało się w rywalizację mocarstw w dobie zimnej

\footnotetext{
${ }^{5}$ M. Colburn, The Republic of Yemen, Development Challenges in the 21st Century, Stacey International, London 2002, s. 12-20.
} 
wojny ${ }^{6} . \mathrm{Z}$ historycznego punktu widzenia znaczące wydaje się także istnienie baz szkoleniowych terrorystów w LDRJ ${ }^{7}$.

Mimo generalnie spokojnych relacji między oboma państwami jemeńskimi w tym okresie, sporadycznie dochodziło między nimi do sporów. Niezależnie od animozji uwarunkowanych trudną sytuacją gospodarczą oraz konfliktem w 1972 r. wskutek braku precyzyjnie wytyczonej linii granicznej, w czasie rokowań pokojowych w Kairze w tym samym roku pojawiły się pierwsze propozycje zjednoczeniowe. Były one następnie hamowane sporami, a nawet konfliktami wewnątrz podzielonego państwa. Do rozmów pokojowych między obydwoma państwami powrócono pod koniec lat 80. XX w. wraz z projektami liberalizacji ruchu granicznego czy wspólnego wydobycia surowców energetycznych. Rok później przywódcy obu państw przyjęli projekt wspólnej konstytucji ${ }^{8}$.

Jemeńska Republika Arabska oraz LDRJ zjednoczyły się 22 maja 1990 r. tworząc Republikę Jemeńską, co pośrednio wpisuje się w realizację idei Wielkiego Jemenu. Uwarunkowanie zjednoczenia wydaje się oczywiste. Jemen był sztucznie podzielony na dwie części mimo wspólnych korzeni historycznych i etnicznych. Celów zjednoczenia można też upatrywać w próbie konsolidacji gospodarek obu państw jemeńskich w celu zapewnienia lepszego rozwoju i tak ubogiego rejonu. Ali Abd Allah Salih został prezydentem, zaś Ali Salim al-Bajd, uprzednio prezydent Południowego Jemenu, zastępcą Saliha. Wydarzenia z tego okresu zbiegają się z agresją Iraku na Kuwejt 2 sierpnia 1990 r. oraz brakiem poparcia ze strony władz Republiki Jemenu dla operacji przeciwko Irakowi w 1991 r. Wówczas prezydent Salih poparł stanowisko Saddama Husajna, co ochłodziło relacje z bogatymi państwami arabskimi. Zaważył tu nie tyle fakt popierania Saddama Husajna, szczególnie przez jemeńskie elity wojskowe, co zasiadanie w tym okresie przez Jemen w Radzie Bezpieczeństwa ONZ jako członek rotacyjny i idąca stąd chęć szerszego zaistnienia w świecie jako państwa sprzeciwiającego

${ }^{6}$ Niezależnie od sympatii bloku wschodniego wobec Jemenu Południowego, jeszcze od końca lat 50. XX w. w Sanie działały misje pomocowe ZSRR oraz ChRL. Zob. T. Y. Ismael, J. S. Ismael, K. Abu Jaber, Politics and government in the Middle East and North Africa, University Press of Florida, Gainesville 1991, s. 427 i n.

7 F. Halliday, Revolution and Foreign Policy. The Case of South Yemen 1967-1987, Westview Press, Cambridge 1990, s. 178-227.

${ }^{8}$ Ibidem. 
się siłowemu usunięciu sił irackich z Kuwejtu. Warto odnotować, że Kuwejt był zaangażowany w próby rozwiązania wewnątrzjemeńskich sporów jeszcze w czasie zimnej wojny. Przesłanki sympatii wobec Bagdadu mogły być też czysto strategiczne. Władze w Sanie spodziewały się wzrostu znaczenia i wpływów Arabii Saudyjskiej w regionie, jeśli Irak zostałby pokonany, co prowadziłoby do dominacji Rijadu nad południem Półwyspu Arabskiego. Oczywiście odpowiedź bogatych państw arabskich znad Zatoki Perskiej była równoznaczna traktowaniu Sany jako „zdrajcy” wobec tejże polityki i przyczyniła się do usunięcia około 800 tys. jemeńskich robotników z Arabii Saudyjskiej w latach 1990-1991, skutkując gwałtownym spadkiem przypływu środków pieniężnych przesyłanych rodzinom przez owych Jemeńczyków, które nie pozostawały bez znaczenia w państwie, w którym gospodarka znajdowała się w stanie rozkładu9.

Po zjednoczeniu obu państw rządząca koalicja była uwikłana w spory wynikające z faworyzowania północnej części państwa przy marginalizowaniu południowej, która dodatkowo znalazła się w trudnej sytuacji gospodarczej po zakończeniu zimnej wojny i utracie dawnych protektorów. Ali Salim al-Bajd dobrowolnie opuścił swój urząd skarżąc się na ignorowanie przez rząd centralny interesów południa kraju, po czym powrócił do Adenu. Mimo trwania negocjacji mających na celu ustabilizowanie sytuacji, w kwietniu 1994 r. doszło do wybuchu wojny domowej. Zdymisjonowano wówczas Al-Bajda, który zbiegł do Omanu. W miesiąc później, dzięki wsparciu ze strony Arabii Saudyjskiej, która poczuła się „zagrożona" zjednoczeniem Jemenu i emanującą z niego destabilizacją, doszło do krótkotrwałej secesji południa, które utworzyło Demokratyczną Republikę Jemenu (nieuznawaną w świecie). Ten epizod zakończył się wraz ze zdobyciem Adenu przez wojska podległe Sanie w lipcu tegoż roku. W konsekwencji prezydent Salih uzyskał absolutną władzę nad krajem, potwierdzoną wyborem przez parlament w październiku 1994 r. W wyborach we wrześniu 1999 r. zwyciężył ponownie. W rok później, w wyniku nowelizacji konstytucji, kadencję prezydenta wydłużono do siedmiu lat. W efek-

${ }^{9}$ R. Hinnebusch, The International Politics of the Middle East, Manchester University Press, Manchester 2003, s. 50 i n. Zob. również: W. Andrew Terrill, The Conflicts in Yemen and U.S. National Security, Strategic Studies Institute, US Army War College, styczeń 2011, s. 34-37. 
cie od wyborów z września 2006 r., Salih sprawował swój urząd aż do masowych wystąpień społecznych w 2011 r., a w lutym 2012 r. opuścił stanowisko. Zastąpił go, na mocy porozumienia wynegocjowanego za pośrednictwem Rady Współpracy (Państw Arabskich) Zatoki Perskiej (Gulf Co-operation Council, GCC), Abd Rabbuh Mansur al-Hadi, wiceprezydent w latach 1994-2012 ${ }^{10}$.

Zjednoczenie nie przyniosło rozwiązania konfliktów nawarstwiających się w okresie zimnej wojny, związanych z problemami gospodarczymi czy społecznymi, np. około 50-procentowym analfabetyzmem. W północno-zachodniej części kraju rozgorzało powstanie szyickiej ludności z plemienia Husi, na południu działa pokojowy Ruch Separatystyczny, zaś w chaos, jaki zapanował w Jemenie od przełomu XX i XXI w., wpisuje się działalność grup ekstremistycznych, szukających schronienia w dobie tzw. globalnej wojny z terroryzmem w kraju, który stopniowo zaczął zbliżać się do statusu państwa upadłego ${ }^{11}$.

\section{Charakterystyka państwa}

Jemen znajduje się w południowo-zachodniej części Półwyspu Arabskiego, nad Morzem Czerwonym, Zatoką Adeńską i Morzem Arabskim. Od północy graniczy z Arabią Saudyjską, a od zachodu z Omanem. Charakteryzuje się stosunkowo dużą powierzchnią wynoszącą 527 tys. $\mathrm{km}^{2}$ przy niewielkiej liczbie ludności, którą w 2012 r. szacowano na około 25,8 mln mieszkańców. Jemen należy do najuboższych państw regionu. PKB na jednego mieszkańca mierzony według parytetu siły nabywczej w 2011 r. wynosił według Banku Światowego jedynie 2248 USD/osobę $e^{12}$. Wiąże się z tym także nieko-

10 Laua Kasinof, Yemen Swears In New President to the Sound of Applause, and Violence, „The New York Times”, 25.02.2012, http://www.nytimes.com/2012/02/26/ world/middleeast/abed-rabu-mansour-hadi-sworn-in-as-yemens-new-president. html? $\mathrm{r}=2$ \&ref=global-home (dostęp: 1.09.2014).

${ }^{11}$ L. Wedeen, Peripheral visions: publics, power, and performance in Yemen, University of Chicago Press, Chicago 2008, s. 148 i n.

12 World Economic Outlook Database - Republic of Yemen, International Monetary Fund, April 2012. Por. Yemen, Rep., World Bank, 2012, http://data.worldbank.org/country/yemen-republic (dostęp: 6.11.2014). 
:::: Jan Bury, Kierunki i uwarunkowania polityki zagranicznej Jemenu...

rzystny Wskaźnik Rozwoju Społecznego (HDI), plasujący Jemen na poziomie niskim ${ }^{13}$.

Charakterystyczną cechą państwa jest górzysty krajobraz. Średnia wysokość nad poziomem morza wynosi około $2000 \mathrm{~m}$. Jedynie wąski pas nadbrzeżny oraz północno-wschodnia część kraju to niziny. Zróżnicowane warunki klimatyczne - od wilgotnego klimatu tropikalnego przy nadbrzeżu, po pustynny, suchy wewnątrz lądu, w tym duże różnice temperatur między dniem i nocą sięgające 30 stopni $\mathrm{C}$ - przez lata utrudniały funkcjonowanie społeczeństwa, ograniczając jego kontakty ze światem zewnętrznym, jak na przykład w okresie panowania dynastii Al-Mutawakkilów (1918-1962). Obecnie poważnym problemem są kurczące się źródła wody pitnej, co może mieć dramatyczne konsekwencje dla sytuacji społecznej i politycznej w tym kraju ${ }^{14}$.

Jemen jest również zróżnicowany pod względem zamieszkujących go muzułmanów: w społeczeństwie spotkać można zarówno sunnitów, jak i szyitów, którzy występują niemal w równych proporcjach. Szyici z plemienia Husi zamieszkują północną część kraju, zaś sunnici dominują na południu i wschodzie.

Gospodarka Jemenu opiera się przede wszystkim na rolnictwie i rybołówstwie, jak i wydobyciu surowców energetycznych. Ziemia uprawna występuje jedynie na około $2 \%$ terytorium państwa. Około $3 / 4$ jemeńskiego eksportu wiąże się z przemysłem wydobywczym ropy naftowej, a 17\% gazu ziemnego ${ }^{15}$. Złoża ropy naftowej jednakże mogą zostać wyczerpane do około 2017 r. stawiając gospodarkę Jemenu w trudnej sytuacji, co w połączeniu z niestabilną demokracją może pogłębić panujący chaos. Poza tym, stosunkowo niewielkie przychody z eksploatacji złóż surowców energetycznych w żaden sposób nie mogły przyczynić się do ratowania upadającej gospodarki. Bezpośrednie inwestycje zagraniczne (FDI) miały związek

${ }^{13}$ Human Development Report 2013. The Rise of the South: Human Progress in a Diverse World, United Nations Development Programme, New York 2013, s. 146, 150.

${ }^{14}$ L. S. Etheredge, Middle East in Transition. Saudi Arabia and Yemen, Encyclopedia Britannica Inc., New York 2011, s. 74 i n.

15 Por. „Yemen Export Treemap”, [w:] R. Haussmann, C. Hidalgo, Atlas of Economic Complexity, MIT Media Lab, the Center for International Development at Harvard University, http://atlas.media.mit.edu/ (dostęp: 6.11.2013). 
głównie z przemysłem wydobywczym surowców energetycznych czy budową terminali załadunkowych skroplonego gazu (LNG).

Po zjednoczeniu obu państw jemeńskich w 1990 r. nie udało się rozwiązać istotnych problemów gospodarczych, politycznych oraz społecznych, które narosły jeszcze w okresie zimnej wojny. Wywodzący się z kręgów wojskowych Ali Abd Allah Salih, Prezydent Jemenu Północnego od 1978 r., a następnie zjednoczonego państwa, pozostawał u władzy aż do 2012 r., będąc jednym z przywódców w świecie arabskim, którzy najdłużej sprawowali swój urząd. Okres jego prezydentury charakteryzowała stagnacja i stopniowe ograniczanie swobód obywatelskich, skutkujące zapaścią gospodarczą. Bezrobocie wynosiło około 40\% w 2011 r., a inflacja osiągnęła pułap $23 \%{ }^{16}$. Kulminacją tych problemów były masowe wystąpienia społeczne w latach 2011 i 2012 w Jemenie. W ich następstwie Salih zrezygnował ze stanowiska.

\section{GŁóWNE KIERUNKI POLITYKI ZAGRANICZNEJ}

Od początku istnienia niepodległego Jemenu można zaobserwować dążenia do jak najszerszego uznania państwowości poprzez członkostwo w międzynarodowych oraz regionalnych organizacjach politycznych. W początkowym okresie zabiegi te sprowadzały się do prób uzyskania identyfikacji przez młode państwo na świecie. Od 1945 r. Jemen jest członkiem-założycielem Ligi Państw Arabskich, w dwa lata później został przyjęty do Zgromadzenia Ogólnego ONZ, zaś w 1969 r. Północny Jemen znalazł się wśród członków Organizacji Konferencji Islamskiej (obecnie: Organizacja Współpracy Islamskiej, OKI). W 1990 r. członkostwo w OKI przyznano zjednoczonej już Republice Jemenu. Co więcej, w dobie zimnej wojny Jemeńska Republika Arabska była członkiem-założycielem Ruchu Państw Niezaangażowanych (Non-Aligned Movement) w 1961 r., a Jemen Ludowo-Demokratyczny dołączył do tego forum w 1970 r. Po zjednoczeniu w 1990 r. Jemen nadal pozostaje aktywny w tej międzynarodowej organizacji, która obecnie zrzesza 120 państw. Fakt ten należy uznać za dystansowanie się przez Je-

\footnotetext{
${ }^{16}$ Por. Global Issues - Yemen, Foreign and Commonwealth Office, http://www.fco. gov.uk/en/global-issues/mena/yemen/ (dostęp: 6.11.2014).
} 
:::: Jan Bury, Kierunki i uwarunkowania polityki zagranicznej Jemenu...

men od głównych mocarstw, których wpływy w XXI w. ciągle pozostają silne na Bliskim Wschodzie. Ma to związek z polityką zapoczątkowaną jeszcze w okresie istnienia Północnego Jemenu, odnoszącą się do zachowania neutralności przy jednoczesnym dążeniu do jedności arabskiej. Niemniej jednak prezydent Salih uczynił ukłon ku Zachodowi, w tym USA, co wiązało się $\mathrm{z}$ dopuszczeniem obcego kapitału do rynku, handlem międzynarodowym, a także zakupami amerykańskiego wyposażenia wojskowego. W tym samym czasie Północny Jemen zachowywał neutralność wobec ZSRR ${ }^{17}$.

Analizując bieżącą politykę Jemenu należy podkreślić okres transformacji, w jakim kraj ten znalazł się od 2012 r. w następstwie tzw. Arabskiej Wiosny oraz brak jawnych strategii odnoszących się do działań władz na arenie międzynarodowej. Nader skromny potencjał wynikający z długotrwałej stagnacji gospodarczej oraz chaos wewnętrzny skutkowały rozproszeniem aktywności międzynarodowej. Z tychże powodów można zaobserwować brak jasnych celów strategicznych oraz konsekwentnego działania służby zagranicznej Jemenu. Wyjątkiem od reguły jest niezmienne poparcie udzielane przez Jemen sprawie palestyńskiej rozumianej jako ogólnoarabska.

Jako przykład niekorzystnych decyzji politycznych Sany należy przytoczyć wspomniane wyżej poparcie udzielone Irakowi w latach 1990-1991, które w konsekwencji przyczyniło się do odcięcia pomocy ze strony państw GCC i usunięcia pracujących w nich Jemeńczyków. Wiele bogatych państw regionu ochłodziło relacje z Jemenem. Niemniej poparcie udzielane Bagdadowi wpisywać się mogło także w ideę Ruchu Państw Niezaangażowanych oraz wcześniejszą współpracę między obydwoma państwami jemeńskimi a Irakiem, którego nie zahamowała przegrana tego ostatniego w wojnie z Koalicją w 1991 r. $^{18}$

${ }^{17}$ W dążenia do neutralności wpisuje się także udział Północnego, a następnie zjednoczonego Jemenu, w utworzeniu Rady Współpracy Arabskiej (ACC) w 1989 r., jako przeciwwagi dla wpływów powstałej w 1981 r. Rady Współpracy Zatoki Perskiej (GCC). Pozostali członkowie ACC wywodzący się z Ruchu Państw Niezaangażowanych to Irak, Egipt oraz Jordania. Organizacja ta uległa jednak rozkładowi po agresji Iraku na Kuwejt w 1990 r. wskutek sprzeczności między jej członkami. Nie można wykluczyć, iż służyła interesom Iraku Saddama Husajna w celu zyskania sojuszników wśród lewicowych państw arabskich. Zob. C. R. Ryan, Jordan and the Rise and Fall of the Arab Cooperation Council, „Middle East Journal” 1998, nr 52, nr 3, s. 386-401.

${ }^{18}$ Por. przyp. 6. 
Zmienne nastawienie w stosunku do Arabii Saudyjskiej w XX i na początku XXI w., przyczyniło się do budowania od 2003 r. przez Królestwo muru bezpieczeństwa na granicy z Jemenem i to mimo uregulowania w $2000 \mathrm{r}$. sporów terytorialnych. $\mathrm{W}$ tym kontekście działania międzynarodowe Jemenu wyraźnie skupiały się na najbliższym otoczeniu. Obecnie najistotniejszymi partnerami są: Liga Państw Arabskich, Organizacja Współpracy Islamskiej, a także Organizacja Narodów Zjednoczonych i ich agendy. Uregulowano stosunki z Omanem oraz Erytreą (w tym spór o Wyspy Hanisz na Morzu Czerwonym zakończony w 1998 r.). Korzystnie zaczęły się rozwijać stosunki gospodarcze z Somalią i Dżibuti. Co istotne, ocenia się, że obecnie w Jemenie może przebywać nawet 1 mln Somalijczyków, głównie poszukujących pracy oraz schronienia w następstwie chaosu, jaki zapanował w Rogu Afryki pod koniec XX w. Dżibuti, jako szybko rozwijające się i stabilne politycznie państwo zamieszkiwane przez znaczącą mniejszość somalijską, jest naturalnym sojusznikiem Sany w regionie. W 2008 r. ogłoszono ambitne plany budowy mostu przez Cieśninę Bab al-Mandab, łączącego dwa kontynenty. Ostateczna realizacja projektu, integrującego Jemen i Dżibuti, którym ma zająć się firma budowlana Tarika bin Ladina, bezsprzecznie przyczyni się do zwiększenia bilansu handlowego, czym pozytywnie wpłynąć może na rewitalizację gospodarki jemeńskiej ${ }^{19}$.

W stosunkach dwustronnych ważnymi partnerami międzynarodowymi Jemenu są: Arabia Saudyjska i pozostałe państwa GCC, wspomniana Somalia oraz Dżibuti, a w dobie globalnej wojny z terroryzmem także USA. Współpraca z hipermocarstwem ma miejsce przede wszystkim w dziedzinie bezpieczeństwa i wojskowości oraz ma związek z operacjami z wykorzystaniem przez rząd USA bezzałogowych aparatów latających przeciwko domniemanym celom $\mathrm{w}$ Jemenie powiązanym $\mathrm{z}$ terroryzmem.

Co ciekawe, Jemen utrzymuje przyjazne stosunki z Indiami oraz Pakistanem mimo animozji między tymi ostatnimi. Jest to uwarunkowane historycznie, gdy terytorium Jemenu i częściowo tychże państw należało do kalifatu.

\footnotetext{
${ }^{19}$ C. Boucek, M. Ottaway, Yemen on the Brink, Carnegie Endowment for Int'l Peace, Washington 2010, s. 1 i n.
} 
:::: Jan Bury, Kierunki i uwarunkowania polityki zagranicznej Jemenu...

Specyficzne relacje łączą Jemen z Iranem. Choć poprawne w końcu XX w., uległy pogorszeniu po podejrzeniach władz w Sanie o wspieranie przez Teheran bojówek z plemienia Husi, które na początku XXI w. wznieciły powstanie przeciwko władzom centralnym. Iran zaprzeczał, równocześnie wysyłając swoje siły na wody Zatoki Adeńskiej czy Morze Arabskie w celu zwalczania piractwa. Niezależnie od oskarżeń, Sana zacieśniała relacje z Teheranem, co cementowały wizyty na szczycie z udziałem prezydentów Alego Abd Allaha Saliha oraz Muhammada Chatamiego w latach 2000 i 2003. Co interesujące, Jemen poparł stanowisko Iranu w kwestii konfliktu tego państwa ze Zjednoczonymi Emiratami Arabskimi o wyspy Wielki Tunb i Mały Tunb w Zatoce Perskiej, które Teheran okupuje od 1971 r. Przyczyny zacieśnionych stosunków między Jemenem i Iranem można upatrywać w kwestiach etniczno-religijnych. Prezydent Salih, jako szyita, był naturalnym sprzymierzeńcem Teheranu, gwarantującym prawa mniejszości oraz dostęp do ważnego portu w Adenie. Jednakże od 2010 r. można zauważyć rozluźnienie relacji z Teheranem na korzyść nowego sojusznika i protektora, czyli USA ${ }^{20}$. Na specjalną uwagę zasługują stosunki jemeńsko-amerykańskie. Zostały nawiązane przez Waszyngton jeszcze w okresie zimnej wojny, najpierw z monarchią z Sany w 1947 r., a następnie z LDRJ w 1967 r. W tym samym roku, po wojnie sześciodniowej między Izraelem i jego arabskimi sąsiadami, Północny Jemen zerwał stosunki z USA, które odbudowano dopiero pięć lat później. Relacje między Waszyngtonem a Adenem były napięte, czego kulminacją było umieszczenie przez Departament Stanu Południowego Jemenu na liście sponsorów międzynarodowego terroryzmu w 1979 r. Równolegle Północny Jemen korzystał z amerykańskiej pomocy rozwojowej wysyłanej za pośrednictwem Amerykańskiej Agencji na rzecz Międzynarodowego Rozwoju (United States Agency for International Development, USAID). Dodatkowo, wraz z Arabią Saudyjską i Koreą Południową, USA inwestowały w modernizację armii Północy od 1979 r., dostarczając Sanie np. myśliwce F-5 wykorzystywane następnie w konflikcie z Południem. Poparcie udzielone przez Jemen Irakowi w 1990 r.

20 I. Blumi, Chaos in Yemen. Societal Collapse and the New Authoritarianism, Routledge, London 2011, s. 67 i n. 
skutkowało wstrzymaniem pomocy przez USA, poza wysyłaniem żywności. Dopiero na początku XXI w. Jemen znów stał się beneficjentem pomocy rozwojowej Waszyngtonu, w tym odbywającej się w ramach programu Departamentu Stanu pn. Middle East Partnership Initiative (MEPI), nakierowanego na rozwój społeczeństwa obywatelskiego i szkolnictwa, reformy gospodarcze i polityczne, w tym obejmujące prawa człowieka. W dobie globalnej wojny z terroryzmem stosunki między Waszyngtonem i Saną są zorientowane na zapobieganie upadkowi państwa jemeńskiego. Pod presją USA społeczność międzynarodowa alokowała w latach 2006-2010 aż 4,7 mld USD na rzecz Jemenu, lecz wypłaty tych środków zostały zamrożone po krwawym tłumieniu wystąpień społecznych w 2011 r. przez Sanę w czasie Arabskiej Wiosny ${ }^{21}$.

Od ataku na amerykański okręt USS Cole 12 października 2000 r. w porcie w Adenie oraz w konsekwencji zamachów terrorystycznych na USA 11 września 2001 r., zacieśnieniu uległa współpraca wojskowa i w dziedzinie bezpieczeństwa między Waszyngtonem i Saną. W jej ramach prezydent Salih wielokrotnie odwiedzał USA. Charakter współpracy jest niejasny i mógł obejmować nawet naruszanie suwerenności Jemenu, co odnosiło się do działań amerykańskich jednostek zbrojnych czy służb specjalnych. W listopadzie 2002 r. w nalocie bezzałogowego aparatu latającego należącego do USA zginął jeden z członków Al-Kaidy, Ka'id Salim Sinan al-Harisi, obywatel USA podejrzewany o sprawstwo kierownicze ataku na okręt USS Cole i inni podejrzani o działalność terrorystyczną ${ }^{22}$. Zamach ten miał podłoże polityczne i wątpliwe, aby był legalny z punktu widzenia ustawodawstwa jemeńskiego czy prawa międzynarodowego. Jemen bowiem nie znajdował się w stanie wojny z USA. W ramach współpracy Waszyngton szkolił i wyposażał jemeńskie służby bezpieczeństwa. Przez amerykański obóz odosobnienia w Guantanamo mogło przewinąć się ponad stu obywateli jemeńskich (około 15 \% wszystkich tam osadzonych), spośród których tylko kilku zostało skazanych przez sądy ${ }^{23}$. Co więcej, bojówki odwołujące się do

${ }^{21}$ US Relations with Yemen, Fact sheet, Bureau of Near Eastern Affairs, US Department of State, 28 August 2013, http://www.state.gov/r/pa/ei/bgn/35836.htm (dostęp: 6.11.2014).

${ }^{22}$ D. Priest, U.S. Citizen Among Those Killed In Yemen Predator Missile Strike, „The Washington Post”, przedruk w: „The Tech”, 8.11.202, vol. 122, nr 54, s. 3.

23 E. Deutschmann, Between Collaboration and Disobedience: The Behavior of the Guantánamo Detainees and its Consequences, „Sociology Working Papers”, (02) (2013), s. 14. 
:::: Jan Bury, Kierunki i uwarunkowania polityki zagranicznej Jemenu...

ideologii Al-Ka'idy rozpoczęły swą działalność w Jemenie, a w szczególności domniemana siatka Al-Ka’idy na Półwyspie Arabskim.

Dwuznaczna polityka władz jemeńskich oraz rosnący interwencjonizm amerykański w tym kraju, odnoszący się do operacji antyterrorystycznych, mogły przyczynić się do zamachu na ambasadę USA w Sanie 17 września 2008 r. W tymże czasie władze jemeńskie musiały stawiać czoła powstaniu szyickiego plemienia Husi na północy, działalności bojówek separatystów z południa pod wodzą byłego wiceprezydenta Al-Bajda oraz grupom terrorystycznym odwołującym się do ideologii Al-Kaidy. Sytuację skomplikował niedoszły zamach 25 grudnia 2009 r. na samolot pasażerski lecący z Amsterdamu do Detroit. Zamachowcem okazał się 23-letni Umar Farouk Abdulmutallab, działający według władz USA na rzecz Al-Kaidy oraz zainspirowany przez kaznodzieję, Anwara al-Awlakiego, obywatela USA, przebywającego wówczas w Jemenie. Wskutek zagrożenia ambasada USA w Sanie została zamknięta jeszcze w $2010 \mathrm{r}$. utrudniając relacje między rządami obydwu państw. Al-Awlaki zginął w Jemenie 30 września 2011 r. w nalocie przeprowadzonym z użyciem amerykańskiego bezzałogowego aparatu latającego wraz z Samirem Khanem, redaktorem wydawanego przez Al-Kaidę na Półwyspie Arabskim pisma Inspire, zaś jego syn Abd ar-Rahman w dwa tygodnie później ${ }^{24}$. Wszyscy byli obywatelami USA, stąd ich zabójstwa z użyciem dronów wywołały uzasadnione kontrowersje wobec jaskrawego naruszenia V poprawki do Konstytucji USA ${ }^{25}$.

24 S. Phillips, Al-Qaeda and the Struggle for Yemen, „Survival”, 53(2011), nr 1, s. 95-120. Por. C. Boucek, M. Ottaway, op.cit., s. 31-44, 75-90.

${ }_{25}$ P. Van Buren, Dead Is Dead: Drone-Killing the Fifth Amendment, „The Huffington Post", 24.07.2014, http://www.huffingtonpost.com/peter-van-buren/dead-is-deaddronekilling_b_5616997.html (dostęp: 6.11.2014). Por. T. Carter, The legal implications of the al-Awlaki assassination, World Socialist Web Site, 10.10.2011, https://www.wsws. org/en/articles/2011/10/awla-o10.html (dostęp: 6.11.2014). Zob. także dokumenty z procesu wytoczonego rządowi USA i jego urzędnikom przez American Civil Liberties Union (ACLU) w związku ze śmiercią Al-Awlakiego, jego syna i Samira Khana: https:// www.aclu.org/national-security/al-aulaqi-v-panetta (dostęp: 6.11.2014). Pozew został jednak odrzucony przez sądy amerykańskie. 


\section{WSPÓŁPRACA GOSPODARCZA}

W kwestie współpracy gospodarczej z partnerami ze świata arabskiego wpisuje się członkostwo Jemenu w Radzie Arabskiej Jedności Gospodarczej (CAEU). Ta powstała jeszcze w dobie zimnej wojny organizacja skupia się na koordynowaniu polityki gospodarczej, w szczególności wymiany handlowej w regionie Bliskiego Wschodu i Północnej Afryki. W 1997 r. w ramach CAEU powstała Strefa Wolnego Handlu (Great Arab Free Trade Area, GAFTA), obejmująca cały świat arabski prócz państw Rogu Afryki oraz Mauretanii, celem aktywizacji wymiany towarów i usług. Członkostwo Jemenu w GAFTA daje możliwość zwiększenia eksportu własnych towarów, szczególnie produktów rolnych przy jednoczesnym zakupie artykułów pierwszej potrzeby oraz usług $w$ atrakcyjnych cenach.

Społeczność międzynarodowa uczestniczy w próbach rewitalizacji i aktywizacji upadającej gospodarki Jemenu. Zabiegi grupy państw zbierających pomoc finansową odbywają się pod egidą procesu mającego doprowadzić do reform gospodarczych i politycznych, znanego jako „Friends of Yemen" (Przyjaciele Jemenu). Datki pochodzą głównie od bogatych krajów arabskich zaniepokojonych chaosem emanującym od państwa zbliżającego się do statusu upadłego, ale również ze świata zachodniego. Działania „Friends of Yemen” zainicjowano jeszcze przed Arabską Wiosną, zaś zasadnicza pomoc trafiała dopiero od 2011 r. w ręce Jemenu, lecz wykorzystywano ją głównie na wydatki związane z bezpieczeństwem, a nie rewitalizację upadającej gospodarki ${ }^{26}$.

Do głównych odbiorców jemeńskich produktów należą Chiny (37\%), Indie (21\%), Tajlandia (7\%), Japonia (5\%) i RPA (5\%). Są to przede wszystkim produkty naftowe. Import do Jemenu odbywa się przede wszystkim ze ZEA (13\%), ChRL (12\%), Indii (7\%), Arabii Saudyjskiej (6\%) oraz Kuwejtu $(4 \%)^{27}$.

${ }^{26}$ The Battle for Yemen. Al-Qaeda and the Struggle for Stability, red. R. Mardini, The Jamestown Foundation, Washington 2010, s. 70 i n.

27 Yemen - Economy, Foreign and Commonwealth Office, 28.02.2012, http://www.fco. gov.uk/en/travel-and-living-abroad/travel-advice-by-country/country-profile/middleeast-north-africa/yemen?profile=economy (dostęp: 6.11.2014). 
:::: Jan Bury, Kierunki i uwarunkowania polityki zagranicznej Jemenu...

\section{Stosunki z Rzeczpospolita Polska}

Nawiązanie stosunków dyplomatycznych między Polską a Jemenem datuje się jeszcze na okres zimnej wojny. W grudniu 1957 r. doszło do wzajemnego uznania poselstw Jemenu Północnego i Polski Ludowej. W 1963 r. status ten uległ rozszerzeniu wraz z nawiązaniem stosunków dyplomatycznych na szczeblu ambasad. Stosunki międzynarodowe z LDRJ Warszawa utrzymywała od 1970 r. Do okresu przemian ustrojowych w Polsce strony jemeńskie były reprezentowane przez dyplomatów akredytowanych w ZSRR lub Niemczech. Polską ambasadę w Sanie otwarto w 1991 r., a jemeńską w Warszawie w $1994 \mathrm{r}^{28}$

Analizując stosunki dwustronne należy zwrócić uwagę na wyjątkowo skromną bazę traktatową między Polską a Jemenem. W dobie zimnej wojny dotyczyła kontaktów handlowych oraz niejawnych umów międzyresortowych (np. MSW PRL z MSW LDRJ). Baza danych traktatowych MSZ RP wymienia tylko jedną aktualną umowę handlową z 1993 r. Dotychczasowe umowy historyczne oraz obecnie obowiązujące wyszczególniono w tabeli 1.

W ramach umowy dwustronnej o udzieleniu kredytu z 1999 r. możliwa była realizacja zakupów towarów przez Ministerstwo Obrony Jemenu w Polsce. W ramach kontraktu do Jemenu wyeksportowano 550 ciężarówek Star 266 dla jemeńskich sił zbrojnych.

W maju 2000 r., w czasie napięć społecznych wewnątrz Jemenu oraz niestabilnej sytuacji, nieznani sprawcy uprowadzili w Sanie Ambasadora RP Krzysztofa Suprowicza. Choć porwany został dość szybko uwolniony, w konsekwencji nastąpiło ochłodzenie stosunków między oboma państwami. Po realizacji kontraktu na dostawę sprzętu wojskowego do Jemenu przez Polskę oraz destabilizacji sytuacji politycznej w Sanie, w sierpniu 2008 r. zamknięto ambasadę RP. Obecnie ambasador RP w Arabii Saudyjskiej jest akredytowany także w Jemenie i Omanie, gdzie Polska nie utrzymuje ze względów ekonomicznych odrębnych placówek ${ }^{29}$.

${ }^{28}$ K. Szczepanik, A. Herman-Łukasik, B. Janicka (red.), Stosunki dyplomatyczne Polski. Informator, t. 4, Afryka i Bliski Wschód 1918-2009, Ministerstwo Spraw Zagranicznych, Biuro Archiwum i Zarządzania Informacją, Warszawa 2010, s. 127-135.

${ }^{29}$ Odpowiedź sekretarza stanu w Ministerstwie Spraw Zagranicznych Jana Borkowskiego - z upoważnienia ministra - na interpelację nr $3432 \mathrm{w}$ sprawie deklaracji 
Tabela 1. Baza traktatowa Polski z Jemenem według danych Departamentu Traktatowego MSZ oraz Archiwum MSZ

\begin{tabular}{|c|c|c|c|c|}
\hline Lp. & $\begin{array}{l}\text { Tytuł } \\
\text { umowy }\end{array}$ & $\begin{array}{l}\text { Data } \\
\text { podpisania }\end{array}$ & $\begin{array}{l}\text { Obowiązuje } \\
\text { od: }\end{array}$ & $\begin{array}{c}\text { Publikacja } \\
\text { w: }\end{array}$ \\
\hline 1. & $\begin{array}{l}\text { Porozumienie o wymianie han- } \\
\text { dlowej i współpracy gospodarczej } \\
\text { i technicznej między Rządem PRL } \\
\text { a Rządem Królestwa Mutawakili } \\
\text { Jemenu. }\end{array}$ & $\begin{array}{l}21 \text { grudnia } \\
1957 r \text {. }\end{array}$ & $\begin{array}{l}21 \text { grudnia } \\
1957 \text { r. }\end{array}$ & \\
\hline 2. & $\begin{array}{l}\text { Umowa kulturalna między Rządem } \\
\text { PRL a Rządem Ludowo-Demokra- } \\
\text { tycznej Republiki Jemenu. }\end{array}$ & $\begin{array}{l}18 \text { stycznia } \\
1973 \mathrm{r} \text {. }\end{array}$ & $\begin{array}{l}25 \text { czerwca } \\
1974 \text { r. }\end{array}$ & $\begin{array}{l}\text { Dz.U. } 1977 \\
\text { nr } 36 \\
\text { poz. } 153\end{array}$ \\
\hline 3. & $\begin{array}{l}\text { Umowa handlowa między Rządem } \\
\text { PRL a Rządem Ludowo-Demokra- } \\
\text { tycznej Republiki Jemenu. }\end{array}$ & $\begin{array}{l}6 \text { września } \\
1988 \text { r. }\end{array}$ & nn. & \\
\hline 4. & $\begin{array}{l}\text { Umowa Handlowa między Rządem } \\
\text { RP a Rządem Republiki Jemenu. }\end{array}$ & $\begin{array}{l}19 \text { listopada } \\
1993 \text { r. }\end{array}$ & $\begin{array}{l}15 \text { sierpnia } \\
1995 \text { r. }\end{array}$ & \\
\hline 5. & $\begin{array}{l}\text { Umowa między Rządem RP a Rzą- } \\
\text { dem Republiki Jemenu o udzieleniu } \\
\text { kredytu. }\end{array}$ & $\begin{array}{l}21 \text { kwietnia } \\
1999 \text { r. }\end{array}$ & $\begin{array}{l}30 \text { czerwca } \\
1999 \text { r. }\end{array}$ & \\
\hline 6. & $\begin{array}{l}\text { Porozumienie między Ministrem } \\
\text { Edukacji Narodowej RP a Mini- } \\
\text { strem Szkolnictwa Wyższego i Ba- } \\
\text { dań Naukowych Rep. Jemeńskiej } \\
\text { o współpracy w dziedzinie oświaty } \\
\text { i szkolnictwa wyższego w latach } \\
\text { 2005-2007. }\end{array}$ & $\begin{array}{l}1 \text { października } \\
2005 \text { r. }\end{array}$ & $\begin{array}{l}1 \text { października } \\
2005 \text { r. }\end{array}$ & $\begin{array}{l}\text { M.P. } 2005 \text {, } \\
\text { nr } 82, \\
\text { poz. } 1155\end{array}$ \\
\hline
\end{tabular}

Wymiana gospodarcza z Jemenem jest pomijana w bilansie handlu zagranicznego Polski. Dane zbiorcze z lat 2003-2012 ilustruje tabela 2. Wymiana w latach 2001-2002 wynosiła około $30 \mathrm{mln}$ USD rocznie i od tego czasu sukcesywnie malała. Niemniej należy zwrócić uwagę na niezmienne od lat dodatnie saldo ${ }^{30}$.

dotyczącej zamykania placówek dyplomatycznych Rzeczypospolitej Polskiej, Warszawa, dnia 8 września 2008 r., http://orka2.sejm.gov.pl/IZ6.nsf/main/6BE66B41 (dostęp: 6.11.2014).

30 Rocznik Statystyczny Handlu Zagranicznego 2015, Główny Urząd Statystyczny, Warszawa 2015, s. 69 i n. 
:::: Jan Bury, Kierunki i uwarunkowania polityki zagranicznej Jemenu...

Warto też wspomnieć o wymianie naukowej między Polską a Jemenem, leżącej w gestii Biura Uznawalności Wykształcenia i Wymiany Międzynarodowej, z której korzystali głównie studenci orientalistyki, wyjeżdżający do Sany na roczne stypendia w celu doskonalenia znajomości języka arabskiego.

Tabela 2. Bilans handlowy Polski z Jemenem w latach 2004-2013

\begin{tabular}{|c|c|c|c|c|}
\hline \hline Rok & Waluta & $\begin{array}{c}\text { Eksport z Polski } \\
\text { do Jemenu (mIn) }\end{array}$ & $\begin{array}{c}\text { Import do Polski } \\
\text { z Jemenu (mln) }\end{array}$ & $\begin{array}{c}\text { Saldo } \\
(\mathbf{m} \mathbf{n})\end{array}$ \\
\hline \hline 2003 & USD & 10,2 & 0,1 & 10,1 \\
\hline 2004 & USD & 12,1 & 0,3 & 11,8 \\
\hline 2005 & USD & 13,4 & 1,1 & 12,3 \\
\hline 2006 & EUR & 7,9 & 0,4 & 7,4 \\
\hline 2007 & EUR & 7,2 & 0,6 & 6,5 \\
\hline 2008 & EUR & 4,2 & 0,4 & 3,7 \\
\hline 2009 & EUR & 10,7 & 0,6 & 10,1 \\
\hline 2010 & EUR & 12,0 & 0,5 & 11,5 \\
\hline 2011 & EUR & 6,1 & 0,8 & 5,3 \\
\hline 2012 & EUR & 15,4 & 0,7 & 14,8 \\
\hline 2013 & EUR & 12,6 & 0,7 & 11,9 \\
\hline
\end{tabular}

Źródło: Syntetyczna informacja o eksporcie i imporcie Polski, Ministerstwo Gospodarki, Departament Strategii i Analiz, lata 2004-2013.

WYZWANIA NA POCZĄTKU XXI w.

Na początku XXI w. Jemen zaczął zbliżać się do statusu państwa upadłego wskutek katastrofalnej sytuacji gospodarczej, a także działalności odśrodkowej. Bezrobocie, korupcja, bieda, brak reform demokratycznych i strukturalnych czy łamanie praw człowieka w ramach autorytarnych rządów prezydenta Saliha spotykały się z kontestacją ze strony zajdyckiego plemienia Husi zorganizowanego w ramach ruchu Młodzi Wierni (Asz-Szabab 
al-Mumin), a także separatystów z południa (Hirak) pod wodzą byłego wiceprezydenta Al-Bajda. Na domiar złego w Jemenie ukonstytuowały się różne radykalne grupy odwołujące się do ideologii Al-Kaidy (np. Al-Kaida na Półwyspie Arabskim, czy Ansar asz-Szari’a), zwalczane przez Sanę i władze USA. Separatyści z południa nasilili swoje działania od 2007 r. Powstańcy z plemienia Husi od 2004 r. prowadzili asymetryczną wojnę przeciwko władzom centralnym po śmierci swego lidera, Husajna Badra ad-Dina al-Husiego, z rąk sił bezpieczeństwa, stawiając czoła nie tylko władzom w Sanie, ale również saudyjskim, interweniującym w Jemenie wobec destabilizacji sytuacji również na granicy. Główne motywy działań powstańców Husi to walka o równouprawnienie oraz sprzeciw wobec nadmiernie zacieśnionych relacji łączących Sanę z USA i Arabią Saudyjską. Zainteresowanie zarówno mocarstwa światowego, jak i regionalnego Jemenem wydaje się jednak uzasadnione ze względu na znaczenie cieśniny Bab al-Mandab czy kwestię wydobycia surowców energetycznych ${ }^{31}$.

W konsekwencji powyższego w 2011 r. Jemen znalazł się na 13. miejscu Indeksu Państw Upadłych (ang. Failed States Index) oraz 164. miejscu Indeksu Percepcji Korupcji (ang. Corruption Perceptions Index, CPI), prowadzonym przez Transparency International (im wyższe miejsce w CPI, tym większa korupcja panuje w danym kraju) ${ }^{32}$. Elity państwa, w kontekście teorii Charlesa Wrighta Millsa ${ }^{33}$, sprowadzały się do sieci rodzinnej prezydenta Saliha, skupiającej w swych rękach znaczną władzę polityczną oraz kontrolującej i ograniczającej dystrybucję dóbr. Przede wszystkim członkowie rodziny zostali umieszczeni w aparacie bezpieczeństwa, np. syn prezydenta, Ahmed Ali Abd Allah Salih, dowodził elitarną Gwardią Republikańską, czyli jednostką chroniącą reżim w razie wystąpień społecznych. Bratanek prezydenta, Jahja Abd Allah Salih, kierował Głównymi Siłami Bezpieczeństwa, stanowiącymi jednostkę antyterrorystyczną. Inny bratanek, Tarik Abd Allah Salih, dowodził Gwardią Prezydencką. Przyrodni brat

${ }^{31}$ S. Phillips, Yemen's Democracy Experiment in Regional Perspective. Patronage and Pluralized Authoritarianism, Palgrave Macmillan, New York, 2008, s. 67-88, 89-112. Por. eadem, Yemen and the Politics of Permanent Crisis, Routledge, New York 2011, s. 24 i n.

${ }^{32}$ Corruption Perceptions Index, Transparency International, 2011, http://www. transparency.org/cpi2011/results (dostęp: 6.11.2014).

33 Zob. C. Wright Mills, The Power Elite, Oxford University Press, Oxford 1956, s. 24 in. 
:::: Jan Bury, Kierunki i uwarunkowania polityki zagranicznej Jemenu...

prezydenta, Muhammad Salih al-Ahmar, dowodził jemeńskim lotnictwem wojskowym. Członkowie rodziny Salih kontrolowali również istotne gałęzie gospodarki Jemenu, np. państwowe linie lotnicze Yemenia czy Jemeńską Korporacją Gospodarczą (YECO) ${ }^{34}$.

Nawarstwiające się problemy gospodarcze, społeczne i polityczne, a także echa rewolucji w Afryce Północnej na przełomie lat 2010 i 2011, przyczyniły się do masowych wystąpień w Jemenie od 27 stycznia 2011 r. Protesty były krwawo tłumione przez władze począwszy od lutego 2011 r., a trzy miesiące później doszło do krwawych walk w stolicy. Jeszcze w czasie wystąpień społecznych, przyrodni brat prezydenta Saliha i jego doradca ds. bezpieczeństwa, gen. Ali Muhsin al-Ahmar Salih, w marcu 2011 r. poparł protestujących i przeszedł na ich stronę. W czerwcu 2011 r. doszło do nieudanego zamachu na życie prezydenta Saliha, a wiceprezydent Abd Rabbuh Mansur al-Hadi został pełniącym obowiązki głowy państwa ${ }^{35}$. Protesty przeciwko władzom trwały nadal. Za udział w nich jemeńska aktywistka Tawakkul Karman otrzymała pokojową Nagrodę Nobla w październiku 2011 r. W miesiąc później, prezydent Salih zaakceptował w Rijadzie plan pokojowy zaproponowany przez GCC, na mocy którego zgodził się ustąpić w zamian za zapewnienie immunitetu. Zastąpił go Abd Rabbuh Mansur al-Hadi, który w 2012 r. nadal pełnił obowiązki głowy państwa. Zmianę sytuacji w Jemenie może przynieść dopiero przyjęcie nowej konstytucji, co zapowiadano na 2014 r. wraz z wyborami parlamentarnymi i prezydenckimi, ostatecznie przesuniętymi na $2015 \mathrm{r}$.

Indeks Państw Upadłych uplasował Jemen w 2013 r. na 6. miejscu w świecie, zaś w jego nowej odsłonie (Fragile States Index) kraj ten zajął 8. miejsce w świecie w 2014 r. CPI w 2013 r. uplasował Jemen na 167. miejscu spośród 175 analizowanych państw ${ }^{36}$. Te dwa wskaźniki jednoznacznie

${ }^{34}$ K. Zimmermann, Saleh Family Network, AEI Critical Threats, American Enterprise Institute, 20.02.2012, http://www.criticalthreats.org (dostęp: 7.11.2014). Por. eadem, Recipe for Failure: American Strategy toward Yemen and al Qaeda in the Arabian Peninsula, AEI Critical Threats, American Enterprise Institute, luty 2012, s. 4 i n.

35 S. Phillips, Who Tried to Kill Ali Abdullah Saleh? The hidden feud behind the revolution in Yemen, „Foreign Policy”, 13.06.2011, http://www.foreignpolicy.com/articles/2011/06/13/who_tried_to_kill_ali_abdullah_saleh (dostęp: 7.11.2014).

${ }^{36}$ Corruption Perceptions Index, Transparency International, 2013, http://www. transparency.org/cpi2011/results (dostęp: 6.11.2014). 
świadczą o upadku państwowości w Jemenie, czego nie była w stanie uratować Konferencja Dialogu Narodowego, która obradowała między 18 marca 2013 a 24 stycznia 2014 r. W czasie jej trwania dochodziło do licznych walk oraz protestów separatystów na południu kraju wskutek nierozwiązania statusu tej prowincji. Dodatkowo odrodził się konflikt z udziałem Husi, który nasilił się w październiku 2013 r. wraz z zabójstwem dwóch delegatów tego plemienia na Konferencję Dialogu Narodowego. Skutkiem tego Husi wycofali się z obrad i zbojkotowali ich wyniki ${ }^{37}$.

Choć dokument końcowy Konferencji Dialogu Narodowego nawoływał do restrukturyzacji parlamentu i Rady Szura, by w równych proporcjach (50\%: 50\%) reprezentowały ludność północy i południa, to nie udało się definitywnie rozwiązać kwestii zbuntowanych prowincji. Wybory prezydenckie w efekcie przesunięto na 2015 r., by dać Al-Hadiemu czas na przeprowadzenie ważnych reform. Kraj tymczasowo podzielono na sześć prowincji federalnych (Aden, Azal, Dżanad, Saba, Tihama i Hadramawt), zaś stolicy przyznano specjalny status niełączący się z żadnym z sześciu regionów. Podział federalny został jednak odrzucony przez przywódców Południa, co jednoznacznie wskazuje na ich dążenia do secesji Adenu i Hadramawtu. Przywódcy Husi również zbojkotowali obrady. Obecnie trwają prace podkomisji, które wyłoniono w czasie obrad Konferencji Dialogu Narodowego, mające na celu przygotowanie nowej konstytucji oraz wypracowanie trwałego modelu podziału państwa albo na zaproponowane sześć prowincji, albo na dwie (północną i południową). Miały one zostać ukończone w styczniu $2015 \mathrm{r}^{38}$ Zamierzenia te jednak upadły wraz z ofensywą sił Husi na stolicę Jemenu, skutkującą odsunięciem od władzy prezydenta Abd Rabbuha Mansura al-Hadiego 22 stycznia 2015 r. i postępującym chaosem politycznym i społecznym. Dnia 25 marca 2015 r. Al-Hadi zbiegł do Arabii Saudyjskiej, zaś kraj ten rozpoczął interwencję zbrojną w Jemenie, mającą na celu rozbicie ruchu Husi. Jest to jednak wątpliwe wobec niskiej

37 G. Hill, P. Salisbury, L. Northedge, J. Kinninmont, Yemen Corruption, Capital Flight and Global Drivers of Conflict, Chatham House, London/wrzesień 2013, s. 1-4.

38 S. W. Day, The 'Non-Conclusion' of Yemen's National Dialogue, „Foreign Policy”, 27.01.2014, http://mideastafrica.foreignpolicy.com/posts/2014/01/27/the_non_conclusion_of_yemen_s_national_dialogue_0. Por. Ali Ibrahim Al-Moshki, National Dialogue Conference Concludes, „Yemen Times”, 28.01.2014, http://www.yementimes.com/en/1750/ news/3398/National-Dialogue-Conference-concludes.htm (dostęp: 6.11.2014). 
:::: Jan Bury, Kierunki i uwarunkowania polityki zagranicznej Jemenu...

zdolności bojowej armii saudyjskiej, zaś konflikt zaczął obejmować także terytorium saudyjskie, na którym działają bojówki Husi.

WNIOSKI

Obecnie Jemen znajduje się $\mathrm{w}$ okresie przejściowym zainicjowanym wydarzeniami Arabskiej Wiosny z lat 2011-2012, który najpewniej potrwa przynajmniej kilka lat. Konieczna jest nowelizacja konstytucji Jemenu, bez której dalsza droga ku demokracji będzie niemożliwa. Niezależnie od następstw masowych wystąpień społecznych, w Jemenie można zaobserwować inne problemy, które negatywnie wpływają na sytuację wewnętrzną tego państwa, ale też na możliwość uprawiania jakiejkolwiek polityki międzynarodowej.

Po pierwsze, Jemen ulega destabilizacji nie tyle na skutek działań odśrodkowych, ile $\mathrm{w}$ wyniku interwencjonizmu USA zaangażowanych w prowadzenie tzw. globalnej wojny z terroryzmem. W ramach tych działań rząd USA zleca naloty na domniemane cele powiązane z terroryzmem na terytorium Jemenu. Według amerykańskiej prasy, a także The Bureau of Investigative Journalism (BIJ), w 2012 r. potwierdzonych ataków z wykorzystaniem bezzałogowych aparatów latających było przynajmniej 29, co stanowi znaczący wzrost względem 2011 r., w którym odnotowano tylko 10 uderzeń $^{39}$. Dane BIJ wskazują także na co najmniej 16 nalotów dronów w Jemenie w 2013 r. i 6 do połowy 2014 r. Szacowana liczba ofiar tych nalotów wyniosła w 2012 r. co najmniej 173 osoby, w 2013 r. co najmniej 63 osoby, a do połowy 2014 r. co najmniej 50 osób ${ }^{40}$. Najpewniej były one możliwe do

39 G. Miller, U.S. drone targets in Yemen raise questions, „The Washington Post”, 3.06. 2012, http://www.washingtonpost.com/world/national-security/us-drone-targets-inyemen-raise-questions/2012/06/02/gJQAP0jz9U_story.html (dostęp: 6.11.2013). Por. idem, White House approves broader Yemen drone campaign, „The Washington Post”, 26.04.2012, http://www.washingtonpost.com/world/national-security/white-house-approves-broaderyemen-drone-campaign/2012/04/25/gIQA82U6hT_story.html?wpisrc=nl_headlines (dostęp: 6.11.2014). 0 chaosie w Jemenie może też świadczyć ucieczka 23 członków Al-Kaidy z pilnie strzeżonego więzienia w Sanie w lutym 2006 r.

40 Zob. The Bureau of Investigative Journalism, Yemen: reported US covert action 2012, http://www.thebureauinvestigates.com/2012/05/08/yemen-reported-us-covert-action2012/ (dostęp: 6.11.2014); Yemen: Reported US covert actions 2013, http://www.thebureauinvestigates.com/2013/01/03/yemen-reported-us-covert-actions-2013/ (dostęp: 
przeprowadzenia po ustąpieniu prezydenta Saliha, który nie należał do zagorzałych zwolenników obcego interwencjonizmu w odróżnieniu od swego następcy, prezydenta Al-Hadiego. W tym kontekście działania rządu USA, choć stanowiące propagandowy sukces, w rzeczywistości nie przywracają porządku ani harmonii w Jemenie, a pogłębiają chaos wynikający z łamania praw człowieka. Waszyngton określa odłam Al-Kaidy na Półwyspie Arabskim mianem najniebezpieczniejszego, choć de facto nie był on w stanie przeprowadzić żadnego znaczącego zamachu na USA. Teza ta wydaje się też wątpliwa w kontekście utworzenia "kalifatu” przez bojówki należące do tzw. Islamskiego Państwa w Iraku i Lewancie (ISIS/ISIL) na fragmentach terytorium Syrii i Iraku.

Po drugie, odpowiedzią na powyższe jest de facto wzrost działań zbrojnych ze strony bojówek Ansar asz-Szari’a, odwołujących się do ideologii Al-Kaidy, podejmujących walkę z władzami postrzeganymi jako marionetki w rękach USA. Najpewniej z tychże powodów doszło do krwawego zamachu w Sanie podczas przygotowań do defilady w maju 2012 r., w którym zginęło ponad 100 osób.

Po trzecie, Jemen boryka się z dwoma nurtami separatystycznymi. Z jednej strony powstanie plemienia Husi w prowincji Sa'ada trwa niemal nieustannie od 2004 r. mimo zawieszenia broni z 2010 r., zaś w działania zbrojne zaangażowała się Arabia Saudyjska i inne państwa GCC. Sytuacja jest uwarunkowana brakiem konstruktywnych rozwiązań, które satysfakcjonowałyby niezadowoloną część społeczeństwa. Z drugiej strony działalność separatystów adeńskich z ruchu Hirak również wpisuje się w pogłębianie chaosu w Jemenie.

Po czwarte, trudna sytuacja gospodarcza i społeczna (około 50\% ludności to analfabeci), a także klęski głodu w latach 2012 i 2013, przybliża Jemen do statusu państwa upadłego, gdy 10 mln Jemeńczyków, czyli prawie połowa mieszkańców, pozostaje niedożywionych ${ }^{41}$.

Z tychże powodów potrzebne są poważne reformy społeczne i gospodarcze, w tym liberalizacja handlu i nakierowanie polityki ekonomicznej na Azję oraz Afrykę, czemu może służyć projekt budowy mostu łączącego

6.11.2014); Yemen: Reported US covert actions 2014, http://www.thebureauinvestigates. com/2014/01/06/yemen-reported-us-covert-actions-2014/ (dostęp: 6.11.2014).

${ }^{41}$ Zob. Aid groups warn of Yemen 'catastrophe', BBC News, 19.07.2012. 
:::: Jan Bury, Kierunki i uwarunkowania polityki zagranicznej Jemenu...

Jemen z Dżibuti. Jednocześnie należy zwrócić uwagę, że pomoc międzynarodowa jest niewystarczająca. Zebrane przez „Friends of Yemen” w 2012 r. 6,4 mld USD stanowi jedynie połowę zapotrzebowania tego państwa na pomoc z zewnątrz. Najpewniej jedynie część tych środków trafi do Jemenu i zostanie wykorzystana przede wszystkim na wsparcie sił bezpieczeństwa, czyli umacnianie prosaudyjskich władz powiązanych z prezydentem Al-Hadim, które pozostają w ścisłych relacjach z USA, a nawet w bezpośredniej zależności. Z tego powodu, niezależnie od zaangażowania świata zewnętrznego, bez przeprowadzenia gruntownych reform w okresie przejściowym Jemenowi będzie groził chaos. Jedyna możliwość rozwiązania obecnego impasu to zakończenie obcego interwencjonizmu w Jemenie oraz międzynarodowa pomoc mająca na celu likwidację głodu oraz rozwój gospodarczy Jemenu.

\section{JAN BURY \\ TRENDS AND DETERMINANTS OF Yemen's foreign POLICY BETWEen 1990 AND 2014}

The article discusses the evolution of Yemeni foreign policy from the unification of the two Yemeni states till the aftermath of the events related to the so-called Arab Spring of 2011. It underlines the determinants and implications of Yemeni foreign policy, particularly in the economic context, as well as the external interventionism, which eventually led to the destabilization. The text also elaborated the Polish direction in Yemeni foreign policy at the turn of the 20th and 21st centuries. 